\title{
The Impact of Canadian Social Discourses on L2 Writing Pedagogy in Ontario
}

\author{
Amir Kalan ${ }^{1}$ \\ ${ }^{1}$ Ontario Institute for Studies in Education, University of Toronto, Toronto, Canada \\ Correspondence: Amir Kalan, Language and Literacies Education Program (LLE), Ontario Institute for Studies \\ in Education of the University of Toronto, Toronto, ON, M5S 1V6, Canada. Tel: 1-647-346-4755. E-mail: \\ amir.kalan@mail.utoronto.ca
}

Received: July 9, 2013 Accepted: July 29, 2013 Online Published: September 4, 2013

doi:10.5539/elt.v6n10p32 URL: http://dx.doi.org/10.5539/elt.v6n10p32

\begin{abstract}
This paper attempts to illustrate the impact of Canadian social, political, and academic discourses on second language writing pedagogy in Ontario schools. Building upon the views that regard teacher knowledge as teachers' sociocultural interactions and lived experiences, and not merely intellectual capabilities gained within teacher preparation, this article proposes that the impact of dominant social discourses on classroom practice might be more profound than teachers' creativity and initiative. This idea is demonstrated by examining the findings of a grounded theory study of frequently employed strategies that can deal with intercultural rhetoric in EAL (English as an additional language) academic writing. Guided by Foucauldian critical discourse analysis, this article approaches the experiences of five Ontario EAL teachers with intercultural rhetoric in order to show the significance of the influence of dominant Canadian social discourses on their practice. This report, in particular, explores possible connections between the popularity of strategies that employ students' first languages in EAL academic writing and dominant social, political, and academic discourses in Canada over the past 50 years. This paper, finally, poses questions about the future of EAL writing pedagogy as anti-multiculturalism discourses gain more dominance in Canada.
\end{abstract}

Keywords: second language writing, intercultural rhetoric, teacher knowledge, discourse analysis

\section{Introduction}

This article attempts to question the impact of EAL (English as an additional language) writing teachers' creativity and knowledge of pedagogy on actual classroom practice. It tries to illustrate that classroom practice is formed as the result of power/knowledge relations in a network of numerous institutions, bodies of knowledge, and individuals. This paper argues that the knowledge of the teacher is indeed an important factor yet with significantly less influence than usually assumed since classroom practice is mainly tailored by dominant social discourses. This idea is explored in this paper by examining the findings of a grounded theory study of the experiences of five Canadian teachers of strategies that can deal with intercultural rhetoric in EAL academic writing. Guided by Foucauldian critical discourse analysis, this article analyzes the influence of dominant Canadian social discourses on the practice of the participants of this study. This paper, in particular, discusses possible connections between the popularity of strategies that employ students' first languages in EAL academic writing and dominant social, political, and academic discourses in Canada over the past 50 years. This paper, finally, poses questions about the future of EAL writing pedagogy as anti-multiculturalism discourses gain more dominance in Canada.

Teacher education, educational policy making, and the educational industry are usually guided by the assumption that teacher knowledge or awareness will automatically translate into effective classroom practice (Freeman \& Johnson, 1998; Larsen-Freeman, 1991; Richards, 1998; Tarone \& Allwright, 2005). In other words, the mechanisms by which teachers are employed and rewarded reflect the underlying belief that teachers with considerable understanding of pedagogy not only possess effective methods but also use them at will.

(Gatbonton, 2000) writes, "Pedagogical knowledge or teachers' constructs of the task of teaching is ... the teacher's accumulated knowledge about the teaching act (e.g., its goals, procedures, strategies) that serves as the basis for his or her classroom behaviour and activities" (p. 586). This intellectual "basis" is commonly targeted in the employment process - suggested in different policy documents, for example the Ontario College of 
Teachers' the Standards of Practice for the Teaching Profession (Ontario College of Teachers, 2013) and is believed to be maintained and complemented by professional development programmes (Eun \& Heining-Boynton, 2007; Fielstein \& Phelps, 2001).

Nevertheless, teacher knowledge as the basis of classroom practice has also been discussed in scholarly literature as a phenomenon formed well beyond teacher education and professional development programmes. Reeves (2009), for instance, stretch the definition of teacher knowledge to include social and cultural elements beyond colleges and professional development workshops. Reeve writes, "Within a sociocultural frame, teacher knowledge finds its origin in the entirety of teachers' lived experiences, not just those experiences within teacher preparation" (p. 109). Similarly, Nespor and Barylske (1991) depart from the views that regard "knowledge as a 'substance' located in the minds, bodies, or 'personal experiences' of individuals." They, instead, describe teacher knowledge as "a situated construction of social networks" (p. 806). Building upon the same line of argument, this paper tries to illustrate the impact of social, political, and academic discourses on classroom practice as sometimes more powerful than teachers' knowledge and initiative.

I have recently conducted a grounded theory study of EAL academic writing strategies that are particularly sensitive to students' cultural background and first languages (Kalan, 2013). The theories generated in this study are grounded in the experiences of some Ontario secondary EAL teachers who were particularly handpicked, through purposive sampling, on account of their successful and informed practice in this regard.

The data in this study, approached by Foucauldian critical discourse analysis, indicated that although the teachers interviewed tried consciously to accommodate their students' cultures, first languages and mother rhetorics, the most frequently employed strategies by the participants of this study were not merely rooted in personal initiative or knowledge. On the other hand, the areas of practice that the participants unanimously regarded as fruitful were indeed closely aligned with dominant political, social and academic discourses in Canadian society over the past 50 years. Thus, as suggested by the findings of my study, a variety of discourses in Canada have, fortunately, favoured culturally conscious EAL teaching strategies. If this conclusion is valid, the following questions arise.

What will happen to actual classroom practice if multicultural discourses are replaced by anti-immigration paradigms especially due to the challenges that the Canadian economy is facing today? Will the Canadian educational system, which is highly centralized, remain considerate of students' mother cultures if multiculturalism is, for instance, considered politically and socially bankrupt? Should a strong focus on training the ideal EAL teacher be replaced by structural changes in the educational system which can give more fluidity to the exchange of pedagogical discourses and practices through creating less centralized and less cumbersome educational systems that dictate pedagogical preferences from top to bottom? These important questions, I hope, underline the significance of the points discussed in this paper.

\section{Theoretical and Methodological Frameworks}

In this inquiry, I employ Foucauldian critical discourse analysis while approaching the data collected for a grounded theory study of practical strategies that can successfully help EAL students and ELL's adopt Anglo-American academic writing rhetoric. Such an approach was dictated by the themes emerging from the data and the findings of the study, which vividly indicated that the strategies developed, or employed, by the participants were closely linked to other Canadian social discourses such as the tendencies of the Canadian academia and the political discourses that favoured multiculturalism and multilingualism. The illustration of this point, I hope, will influence our approach to creating desirable classroom pedagogy by emphasizing the role of current, and especially dominant social discourses, rather than a constant fixation on teacher training and professional development which, of course, have their own place in the whole picture.

Literature on Foucauldian research methodologies hosts many voices doubting the existence of clear definitions of such approaches (Davies, 2005; Meadmore, Hatcher \& McWilliam, 2000; Tamboukou, 1999). Foucault (1994) himself also deliberately avoided specifying research methods that can be categorized as Foucauldian discourse analysis, which indeed adds to the ambiguities in this territory of inquiry. In order to avoid the confusions about the precise characteristics of research methodologies rooted in Foucault's views, the following explanation about the method adopted for this particular inquiry might be helpful.

The method of analysis of data for this inquiry is "critical discourse analysis" (Blommaert \& Bulcaen, 2000) as opposed to "formal linguistic discourse analysis" (Frow, 1989) and "empirical discourse analysis" (Van Dijk, n.d.). While formal linguistic and empirical discourse analyses focus on "discourse" as linguistic passages, semiotic texts, and forms of human communication, critical discourse analysis not only explores language and social communication, but regards institutions, organizations, social practices, scientific disciplines, religions, 
media, individuals and so on as discourses constantly involved in power relations.

Power, Foucault (2002) suggests, constantly circulates in all directions and to all social levels. The distribution and contraction of power is tied to innumerable social nodes, whose positions delicately but ceaselessly switch. Gaining power happens partly through an exchange of ideas manufactured in accordance with claims of different discourses to the "Truth." Hence, knowledge is hardly rooted in individual speculation or experimentation. Instead, "knowledge," in fact, is our "will to knowledge" (Yong, 1981), our "will to truth" (Foucault, 1981) and our "claim" to it is based on the dictates of the dominant discourses involved in social power games and institutional interactions.

This paper, harmonious with this view, examines the influence of Canadian social, political, and academic discourses on EAL classroom practice in order to show how EAL writing pedagogies are shaped by the interaction between different discourses, for example, institutions, policies, and academics - outside the classroom. In the same manner, it approaches the experiences of some successful Ontario EAL instructors as the result of the give-and-take of dominant discourses in Canadian society rather than individual achievements. It tries to illustrate how fruitful pedagogy results mainly from the interactions between academic, social, and political discourses and historical circumstances rather than "training" ideal teachers even though those teachers, as the participants of this study, are particularly aware, knowledgeable, creative, and enthusiastic.

In other words, this report is a "thick description" (Scarboro, Campbell, \& Stave, 1994) of successful EAL writing pedagogy in the context of the network of the Canadian academia, society, and politics. In the Discussion section, which follows a brief review of the grounded theory study in question in the next section, I will illustrate how social, political, and academic discourses in Canada have been at work to give weight to certain EAL academic writing strategies.

\section{A Brief Description of the Study and Its Findings}

The study was a qualitative research project that tried to theorize practical strategies that helped learners of English as an additional language to adopt Anglo-American academic rhetoric in order to write essays and academic papers. This investigation particularly focused on strategies that regarded English academic writing as only one possible written construct of a certain cultural and rhetorical background. The study, also, explored approaches that were informed by the fact that EAL students came to classrooms in English speaking countries with a strong notion of what great writing was in their first languages and rhetorics. A search for strategies and approaches of this nature was deliberately opted for in order to showcase successful experiences of writing instructors who went beyond traditional drilling exercises, which largely ignore the student's rhetorical background and start with lessons on Anglo-American "paragraph writing," the "topic sentence," and "supporting details." These theories were grounded in in-depth open-ended interviews with some Canadian secondary school EAL writing instructors who had tried to develop methods for interacting with the rhetorical traditions that secondary EAL students and ELL's brought with them into the classroom. Their experiences, thus, were regarded as slightly different to mainstream classroom practice, and consequently inspirational for other teachers to learn about. In other words, the teachers interviewed were particularly approached since they were considered more creative and resourceful as far as the presence of students' first languages and rhetorics in the process of writing was concerned.

The strategies theorized in this study are listed at the end of this section in order of their popularity, equality shared among the participants, and the frequency of appearance in the data. The most frequently employed strategies in the list are later compared with dominant social, political, and academic discourses regarding EAL and second language education discourses in Canada in order to draw parallels between dominant discourses in Canadian society and actual classroom practice by examining the strategies favoured most by the participants in this study. This comparison proves that the influence of dominant social discourses on classroom practice might indeed outweigh the impact of teachers' knowledge and their personal initiative even among exemplary teachers.

Almost half a century ago, Kaplan (1966) started a conversation in scholarly literature about the relationship between non-English writing rhetorical patterns and the struggles of EAL students with English academic writing. This area of inquiry, initiated by Kaplan, was labeled "contrastive rhetoric," which, after modification and critique, has been renamed "intercultural rhetoric" (Connor, 2002). "Contrastive rhetoric is an area of research in second language acquisition that identifies problems in composition encountered by second language writers and, by referring to the rhetorical strategies of the first language, attempts to explain them" (Connor 1996, p. 5). The renaming of the field as "intercultural rhetoric" seemed necessary because of two major reasons: first, constant criticism of Kaplan's contrastive rhetoric, whose speculations seemed to indicate that Anglo-American rhetoric was superior to Eastern rhetoric and; second, new directions in contrastive rhetoric which favoured 
interactions between rhetorics rather than conflict, friction, and opposition.

Despite all the theoretical speculations about intercultural rhetoric, some researchers believe that very little theory has translated into actual classroom practice which is sensitive to students' first languages and cultures (Kubota \& Lehner, 2004; Walker, 2011). The same concerns about practice also have been expressed about Canadian EAL classrooms (Steinman 2003, p. 88). Accordingly, in order to fill this gap, this study tried to explore the experiences of some exemplary teachers to make strategies that were sensitive to the interactions between Anglo-American writing rhetoric and students' mother rhetorics visible.

Practical strategies concerned with students' native rhetorics and literacies usually stem from other fields such as multiliteracies, for example creating "identity texts" (Cummins, 2011), genre theories, for instance the recommendations of the Australian Genre School (Hyon, 1996), process writing (Susser, 1994), and post-process writing pedagogy (Kent, 1999). Although these practical measures might have been inspired by discussions about rhetoric and although they can successfully deal with students' rhetorical confusion, these suggestions usually cover more ground than contrastive rhetoric. This study aimed for a more transparent organization of activities that could particularly impact EAL students' rhetorical performance to help teachers redefine effective classroom practice in EAL academic writing classes. Additionally, a clearer view of such practices in Ontario schools would lend itself more comfortably to analyzing such practices in the context of dominant discourses in Canada for the purposes of this paper.

There are at least two important reasons why the academic writing skills of EAL students in Canada should be of grave concern. First, in contrast with conversational proficiency, EAL students might have to spend years (at least five and usually longer) to reach satisfactory academic proficiency in English (Cummins, 2007). EAL academic writing, indeed, is an essential part of a student's academic fluency.

Second, similar to other English speaking countries, in Canada, written language is the most important channel of formal and academic communication. This, nevertheless, is not necessarily the same for all the cultures whose members Canada welcomes as its new citizens. In addition to the fact that those cultures might use other written rhetorical patterns, they may more frequently employ non-written media such as visual or oral presentations to communicate and express their opinions.

Thus, Canadian educational systems should be ready to meet two challenges in regard to EAL writing pedagogy, (a) EAL writing as a linguistic skill and (b) EAL writing as a cultural paradigm change. EAL teachers, accordingly, might have to take the role of cultural counsellors as well as language teachers in order to help students make bridges between cultures, styles of writing, and rhetorical traditions.

This study, first and foremost, was initiated in order to explore the practical implications of theoretical discussions about contrastive or intercultural rhetoric since most of the concerns and speculations about contrastive rhetoric were presented at the level of theory. This study attempted to see how exceptional or alternative Ontario teachers dealt with intercultural rhetoric. Furthermore, a transparent categorization of such theories could clarify the relation between teachers' experiences in the classroom and social, political, and academic conversations outside the classroom. The present article is a report on the latter goal outlined above.

The methodology adopted for this research was the qualitative research approach grounded theory. This study, following established methodological frameworks of grounded theory (Corbin \& Strauss, 2008), attempted to generate theories based on narratives provided by five EAL academic writing instructors in Ontario secondary schools of their rhetorically sensitive classroom practice.

Searching for participants started through a network of university instructors, researchers, EAL teachers, Ontario English teachers, and students. Five participants were interviewed in the course of this study. There were two criteria to satisfy. First, the participants were carefully handpicked to represent a variety of educational institutions in Ontario. Second, the participants who were chosen were EAL teachers who had somehow tried to move beyond drills and controlled exercises. The second criterion is particularly important in this paper since this report tries to illustrate that even the practice of exceptionally aware, creative and enthusiastic teachers is influenced by power/knowledge discourses outside the classroom. This illustration, I hope, will help us rethink our definition of teachers' knowledge of pedagogy to include the impact of educational structures on the performance of teacher both positively, such as the experiences of the participants of this study, and negatively.

Creswell (1998), along with many other research methodology text book writers, suggests that, in a grounded theory study, in order to "saturate categories" and detail a theory, one needs to interview "20 to 30 people" (p. 56). Creswell borrows his discussions about grounded theory, including the concept of saturation, from Strauss, one of the founders of grounded theory as a qualitative approach. From Strauss's point of view the sample size in 
this project $(\mathrm{n}=5)$ cannot help interview data reach "saturation" ("when no new data are emerging" (Corbin \& Strauss, 2008, p. 143)).

Although, as indicated by the reference to Corbin and Strauss at the beginning of this section, this project followed Strauss's (2008) views of grounded theory as the main structural backbone of the methods employed. Nevertheless, as far as the number of participants was concerned, I tended towards Charmaz's (2000) "constructivist grounded theory." Consistent with Charmaz's ideas reflected in her article "Grounded Theory: Objectivist and Constructivist Methods," the researcher of this project holds that themes do not always objectively emerge from saturated data. Themes, on the other hand, can be constructed by the participants and the researcher. With this view of grounded theory, a larger number of participants would not necessarily lead to more valid findings but to a different set or a larger number of themes. In other words, a change in the number of participants does not affect validity but the scope and substance of the investigation and its findings.

My first participant was Uluriaq (all the names are pseudonyms). She is an ESL writing instructor and an ESL consultant in a major school board in Ontario. She also supervises a TESOL program in Waterloo, Ontario. What made Uluriaq a particularly valuable candidate for this project was the dual language book club that she had run for years. My second participant was Puja. Puja is a seasoned ESL teacher with 15 years of teaching experience both in Canada and abroad. She is at the moment teaching in an esteemed all-girls independent Toronto high school, with a strong academic orientation and a large EAL population. Oki, my third participant, has been seriously involved in literacy projects with different youth circles in addition to his experiences with Ontario high school EAL students and ELL's. Moreover, what distinguishes him from the first two participants is his engagement with research. Oki is a doctoral student at a major Canadian University in Ontario, working on a research project about a multiliteracies related theme.

The fourth participant, Panikpak is not an ESL teacher. She is an English teacher. Her classes, however, usually host a great number of ELL's (up to $40 \%$ of the students). Besides, her main form of assessment has traditionally been typical North American persuasive and argumentative essays. Niriuniq, the fifth participant has been tutoring ESL students in academic writing. She is also a teacher assistant at a prominent university in Ontario. Niriuniq is an essay grader and deals with year-one undergraduate students' papers. Niriuniq's views, thus, have been included in this project for a better understanding of second rhetoric problems that ESL secondary students take with them into higher education.

\subsection{Practical Strategies for Approaching Intercultural Rhetoric}

Three subcategories of themes, focusing on practical strategies beyond drills and exercises, emerged from the data: (1) strategies that tap into students' first languages and mother rhetorics, (2) strategies that take advantage of non-academic written forms and non-written modes of expression, and (3) genre-oriented strategies.

\subsubsection{Tapping into Students' First Languages and Mother Rhetorics}

This subcategory hosts the majority of the themes that emerged from the data. These strategies are informed by the underlying belief that EAL students already possess literacies that are communicated more effectively in their mother tongue. As a result, making room for the first language, in an attempt to help those literacies surface, is a wise pedagogical investment. The participants gave the following recommendations for using the potential of students' first languages in the process of teaching EAL academic writing.

First, all the participants agreed that even the mere act of consolidating students' knowledge of their first languages, particularly enabling them to master advanced levels, could boost their understanding of academic writing in English. Puja, for instance, said, "I would say keep writing in your first language. Do what you do in your first language. If you can take a first language course, please do that." She emphasized that she particularly encouraged her students to interact with academic concepts in their first languages.

Second, in addition to the advantages of constant interaction with the first language, the participants, also, believed that students' first languages and rhetorics could be tapped into while they were handling particular writing tasks in English. The participants had experienced a number of ways to employ students' first languages and mother rhetorics. They, for example, invited students to write and recite in their first language, and then had them translate what they had written into English. They encouraged their students to plan their essays in their first language before they actually started with writing them. Also, they asked them to write in both languages simultaneously and do dual language projects.

Third, two of the participants, Uluriaq and Panikpak, emphasized that they used the student's first language and mother rhetoric for assessment as well, particularly for diagnostic and formative assessment. Uluriaq thought it natural to start academic writing lessons with short pieces of writing in the student's first language. This, she 
maintained, would give teachers a great opportunity to see where their students are coming from rhetorically and what perceptions they have of good quality writing. "You see, first of all, what their literacy level is in their first language, but not only that, how they structure things. How their culture and their way of thinking ties into their style of writing. I think that's really important."

\subsubsection{Taking Advantage of Non-Academic Written Forms and Non-Written Modes of Expression}

All the participants thought that students should be able to employ the modes of expression that they are accustomed to, especially prior to the actual academic writing task, in order to express themselves comfortably and make their ideas transparent without any concern about, or fear of, making formalistic or rhetorical mistakes. The teachers specifically spoke of their experiences with two modes of expression, free-form writing and conversation.

All the teachers agreed that free-from writing was a simple activity, yet it functioned as a painless transition from everyday English to academic English. Free-form writing, the participants held, can provide a sizable arena for students to experiment linguistically without worrying about the mistakes that they might make when writing academic papers. Additionally, free-form writing is very personal. This characteristic will let students express their deepest emotions and usually unsaid opinions. The personal quality of such messages, when expressed in public can facilitate community building and create respect, and consequently confidence, for students.

Next to free-form writing, pre-writing conversations were commonly experienced by the participants. Similar to free-from writing, casual conversations with pears or the teacher will let students express their ideas without struggling with technicalities of academic writing. Having a casual conversation, students voice their opinions without any anxiety, for instance, about spelling of punctuation. If students are admired for their opinions before they are required to write passages free of grammatical errors, they will feel more confident in the process of writing.

\subsubsection{Creating Genre Transparency}

The dominant theme in the participants' discussions about genre was an emphasis on creating transparency. All the participants unanimously agreed that teachers need to make students conscious of the fact that English essay writing is a unique written genre which has been formed by certain historical and social circumstances. Students, they underlined, should be aware that if they face challenges, while trying to adopt Anglo-American rhetoric, they should not feel guilty or inadequate. Neither should they doubt their ability as good writers. All the teachers in this investigation told stories of their attempts to make this fact transparent that English academic writing was one genre among many. Moreover, they made it clear to their students that no genre was superior to another. We choose to write in a particular genre merely based on the dictates of context and circumstance. Thus, students can learn that they can value both their native rhetoric and their second rhetoric.

The following figure represents all the strategies that the participants of this study had employed in their classes.

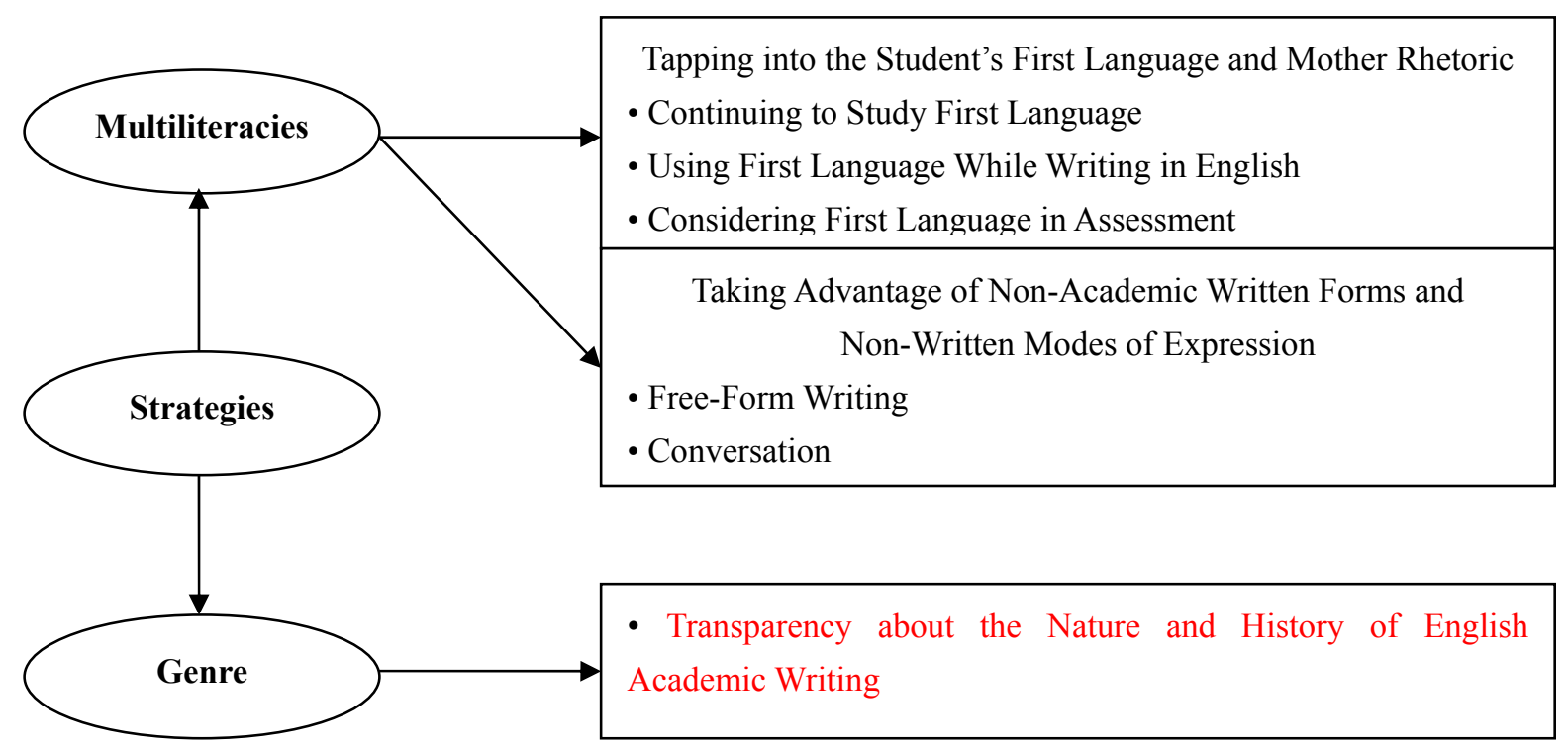

Figure 1. Strategies for approaching intercultural rhetoric 
For the purposes of this paper, however, the same sets of strategies are represented in the next graph with a closer look at the space each category of activities occupied in the data. This graph more visibly displays how frequently each family of strategies was discussed and which themes loomed larger in the data. Visual representations like Figure 1, which only lists the strategies discussed in the interviews, may not be able to visibly display the real extent of the dominance of popular themes in interview conversations. Figure 2, on the other hand, clearly illustrates that $70 \%$ of the conversation about practical strategies was indeed about tapping into the potential of students' first languages during the process of teaching academic writing. The dominance of this set of strategies in the data was measured by a close observation of the physical space occupied by teachers' narratives of each strategy in the transcriptions. Further analysis, also, showed that the data presented in the following graph happened to match the dominant academic, social and, political discourses in Canadian society, which will be discussed in the next section.

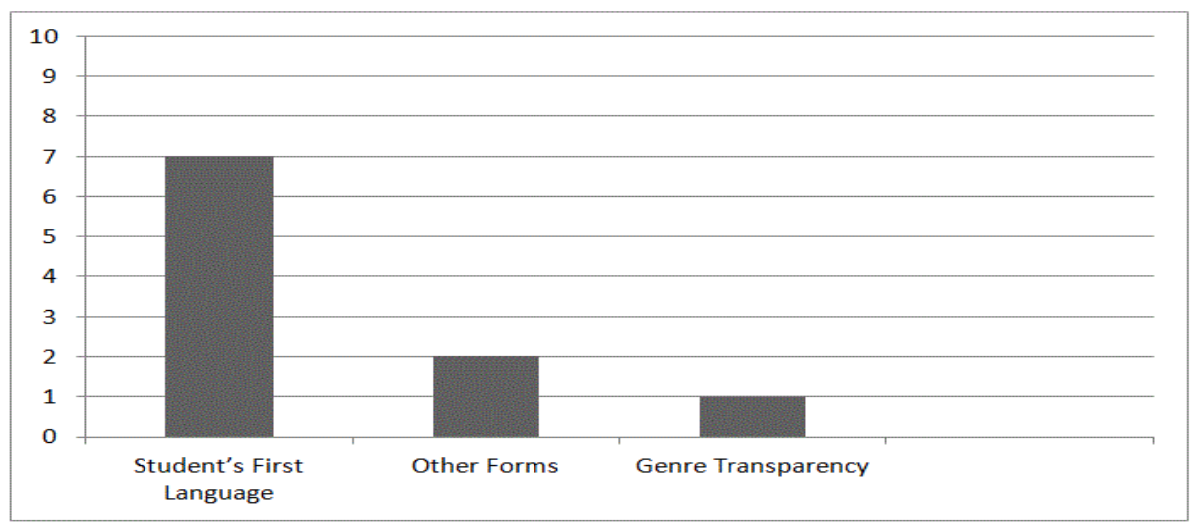

Figure 2. Frequency of strategies employed by participants

\section{Discussion}

The findings of this investigation indicate that paying attention to students' first languages in Ontario classrooms is a relatively established practice. All the participants said that they encouraged EAL students and ELL's to continue studying their first languages. They also used their students' first languages in the process of writing in English and for different forms of assessment.

Unlike other strategies, when students' first languages were mentioned in the interviews, the participants spoke about political, social, and academic discourses outside their classroom which supported their practice. The teachers particularly referred to the official documents that required or recommended such practices and frequently mentioned the names of Canadian researchers who worked on a variety of dual language projects and bilingualism. Puja, for example, shared her knowledge of academic discourses surrounding her practice as follows:

I would never say you can't do that anymore, you know? And I would say keep writing in your first language. Do what you do in first language. If you can take the first language class, please do that. Because as we know from the work of Jim Cummins, and also the work of Fred Genesee in Montreal-These people have all done significant research to prove that if you retain and develop your mother tongue to the highest level possible, it's easier to add other languages, right? So you want to have that structure developed as much as possible even if your [unclear] is slightly different. And the way to do that of course is to read and to write in your first language in the most sophisticated way you can.

The interview data suggested that in addition to the participants' personal attachment to practices considering the student's first culture, language, and rhetoric, the teachers interviewed, as illustrated in Puja's comments above, demonstrated a tendency towards including references to other academic and social discourses in the conversation as well. Furthermore, three of the participants (Uluriaq, Oki, and Niriuniq) were directly connected to the academic world. Current research on different aspects of second language education informed their comments and they made frequent references to research findings.

From the 1870's for almost one century, the discourses that created residential schools in Canada reflected the dominant mentality about students' mother cultures among English-speaking policy makers. Fueled by colonial othering (Van Houtum \& Van Naerssen, 2002), residential schools aimed at "killing the Indian in the child" 
(Note 1). In this period, there was an emphasis on turning non-English students "into good Canadians as quickly as possible, which meant separating them from their first language and culture and immersing them in English, an attitude which came through strongly in J.T.M. Anderson's book, The Education of the New Canadian (1918)" (Ashworth, 1992, p. 36). It was not until after the Second World War that signs of accepting the language of the "other" became comfortably visible in Canadian political discourses. In 1963, Prime Minister Pearson formed the Royal Commission on Bilingualism and Biculturalism and Canada officially and, in 1969, Canada became a bilingual nation (Official Languages Act, 1969). The next paradigm shift from the bilingualism discourse to the multiculturalism paradigm happened in Prime Minister Trudeau's political arena:

Canada's citizens come from almost every country in the world, and bring with them every major world religion and language. This cultural diversity endows all Canadians with a great variety of human experience. The Government regards this as a heritage to treasure and believes that Canada would be the poorer if we adopted assimilation programmes forcing our citizens to forsake and forget the cultures they have brought to us. (Canada. Federal Government, 1971, p. 8580)

Since then multiculturalism and diversity have been important components of dominant political and social discourses in Canada. These concepts have considerably influenced educational systems in Canada as well. In the same fashion, teaching English as an additional language, and generally second language education, has had its own share of this conversation and borrowed a great deal from it (MacPherson et al., 2004).

The teaching and learning of English as a second language plays a central role in the realization of Canadian multiculturalism. ESL teachers can profoundly affect students' views of their first languages and cultures, and thereby can affect whether they pursue multilingual intercultural outcomes or subtractive assimilation. Not only can they teach "Canadian" human rights values, but also how to become intercultural, that is, how to move across cultures in a way that is tolerant of conflicting perspectives and deeply respectful of people's lived differences (p. 5).

The political and social conversations favouring multiculturalism paved the way for academic investigations into second language education, bilingualism, and multilingualism. Harmonious with dominant political and social discourses of the time, researchers keen on language and cultural diversity gained a considerable voice. Similarly, in an atmosphere charged with positive attitudes towards students' first languages and cultures, the recommendations of these researchers comfortably found their way into teacher education and TESOL programmes.

Although not in the centre of the comments of the teachers that I interviewed, these discursive relations were always present in the margins of our conversations and indeed, in total, formed a sizable chunk of the data collected. Professor Jim Cummins at Ontario Institute for Studies in Education was the most commonly referenced researcher in the interviews. In the discursive networks emerging from the data, he represented the academic discourse which connected policy makers with practitioners. The participants recognized the importance of such an influential academic discourse and agreed that "Jim Cummins began to change the language and the direction of the debate in ways that are now firmly ingrained, largely accepted and internationally acclaimed" (Cummins, Baker, \& Hornberger, 2001, p.5).

According to the discursive patterns described above, I believe that the dominance of strategies employing students' first languages by Ontario teachers, as indicated by my study, has been mainly established by political, social, and academic discourses underlining diversity in second language education in Canada, and less by teacher knowledge even among more motivated and creative teachers. By developing this argument, I hope I can question the impact of teacher knowledge on actual classroom practice and invite attention to the influence of discourses outside the classroom on the pedagogies teachers choose to adopt.

Figure 2 in the Findings Section shows that strategies which employ students' first languages make up the majority of practices experienced by the participants. Despite the enthusiasm among the teachers about multimodal activities, no particular story was told about using visual or pictorial media (Brisk \& Harrington, 2000; Kasper, 2000) in the preparatory steps that led to actual writing of an academic piece. The philosophies of EAL writing teaching shared by the participants make it difficult to believe that any of them would support such a move in the classroom less than passionately; however, specific examples were not recorded in the data.

In the same manner, based on the data collected for this study and its findings, one can see that, in Ontario schools, activities with multiliteracies bent comfortably outnumber activities concerned with genre. Unlike the United States, Australia, and Europe, which, in different periods, have witnessed different genre movements grow (Hyon, 1996), genre studies has never become as popular a discourse in Canada as multiliteracies speculations in second language education with a focus on students' first languages. Thus, the tendency among 
Canadian EAL educators to focus on students' first languages and cultures must have been strengthened by the discursive patters described above rather than individual knowledge and initiative.

In addition to an illustration of the relationship between political, social, and academic discourses and classroom practice, this paper also aims to pose two questions for further inquiry. First, although dominant political and social discourses in Canada have strengthened some extremely helpful pedagogical practices, they might have isolated some other approaches such as a genre approach to EAL academic writing as discussed above. This lack of attention to other pedagogies that are potentially fruitful might be the result of the centralised nature of the Canadian educational system. Now the question is can loosening the structure of the educational system in Canada create more room for teacher knowledge and experimentation? And accordingly, can such decentralization help teachers explore more pedagogical possibilities.

Second, political and social discourses in Canada over the past 50 years, have happened to be harmonious with the academic discourses that are sensitive to students' mother tongues and cultures. If classroom practices, more than any other factor, are formed in accordance with dominant discourses in society, what will happen to second language education in case of dramatic shifts of attitude to anti-multicultural and anti-multilingual positions. Citing Tatalovich (1995), Wiley (2007) writes, "From the perspective of educational languages rights, the $21^{\text {st }}$ century begins with the echoes of early $20^{\text {th }}$ century restrictionism" (p. 103). Also in Canada, one can increasingly hear voices that regard multicultural polices as bankrupt and outdated (Appiah, 2010; Ghosh, 2011; Martin, 2007; Wente, 2010). Whether or not these arguments are sound, how would they affect classroom practice on the occasion that these discourses become dominate in Canadian society and politics?

\section{Conclusion}

This paper, thus, has tried to illustrate the impact of social, political, and academic discourses in Canada, over the past decades, on pedagogical choices made by EAL writing instructors in Ontario. By showing the connections between discursive give-and-take in Canadian society and classroom practice, I have tried to question the importance of teacher knowledge and initiative even among more informed and creative teachers. Failing to pay attention to the role of dominant social discourses on actual classroom practice might result in isolating useful pedagogical approaches, for instance, genre theory in the case that has been discussed in this paper. Moreover, considering the impact of social discourses on teacher knowledge and performance, we will have to seriously think about possible shifts in classroom practice as discourses favouring anti-multiculturalism, and consequently anti-multilingualism, gain more weight in Canada.

\section{References}

Anderson, J. T. M. (1918). The education of the new Canadian. Toronto: Dent.

Appiah, K. A. (2010/10/06). The multicultural mirage. The Globe and Mail, A, 25.

Ashworth, M. (1992). Views and visions. In B. Burnaby, \& A. Cumming (Eds.), Socio-political aspects of ESL (pp. 35-49).

Brisk, M. E., \& Harrington, M. M. (2000). Literacy and bilingualism: A handbook for all teachers. Mahwa, NJ: Lawrence Erlbaum Associates. PMid: 10699105.

Blommaert, J., \& Bulcaen, C. (2000). Critical discourse analysis. Annual Review of Anthropology, 29, 447-466. http://dx.doi.org/10.1146/annurev.anthro.29.1.447

Canada. Federal, Government. (1971). Federal government's response to book IV of the report of the royal commission on bilingualism and biculturalism. Document tabled in the House of Commons on 8 October, 1971, by the Prime Minister. Ottawa: Queen's Printer.

Charmaz, K. (2000). Grounded theory: Objectivist and constructivist methods. In N. Denzin, \& Y. Lincoln (Eds.), Handbook of qualitative research (2nd ed., pp. 509-535). Thousand Oaks, CA: Sage.

Connor, U. (1996). Contrastive Rhetoric: Cross-cultural aspects of second-language writing. New York: Cambridge University.

Connor, U. (2002). New directions in contrastive rhetoric. TESOL Quarterly, 36(4), 493-510. http://dx.doi.org/10.2307/3588238

Corbin, J., \& Strauss, A. (2008). Basics of qualitative research (3rd ed.). Thousand Oaks: Sage.

Creswell, J. W. (1998). Qualitative inquiry and research design: Choosing among five traditions. Thousand Oaks, California: SAGE Publications.

Cummins, J., Baker, C., \& Hornberger, N. H. (2001). An introductory reader to the writings of Jim Cummins. 
Clevedon, England: Multilingual Matters.

Cummins, J. (2007). Language interactions in the classroom: From coercive to collaborative relations of power. In O. Garcia, \& C. Baker (Eds.), Bilingual education: An introductory reader (pp. 108-136). New York: Multilingual Matters Ltd.

Cummins, J., \& Early, M. (2011). Identity texts: The collaborative creation of power in multilingual schools. Stoke-on-Trent: Trentham Books.

Davies, B. (2005). The (im)possibility of intellectual work in Neoliberal regimes. Discourse: Studies in the Cultural Politics of Education, 26(1), 1-14. http://dx.doi.org/10.1080/01596300500039310

Eun, B., \& Heining-Boynton, A. L. (2007). Impact of an English-as-a-second-language professional development program. The Journal of Educational Research, 101(1), 36-49. http://dx.doi.org/10.3200/JOER.101.1.36-49

Fielstein, L., \& Phelps, P. H. (2001). Introduction to teaching: Rewards and realities. Belmont, CA: Wadsworth/Thomson Learning.

Foucault, M. (1981). The order of discourse. In R. Young (Ed.), Untying the text: A post-structural anthology (pp. 48-78). Boston, MA: Routledge \& Kegan Paul.

Foucault, M. (1994). An interview with Michel Foucault. In J. D. Faubion (Ed.), Power, (vol. 3, pp. 239-297). NewYork: The New Press.

Foucault, M. (2002). The archaeology of knowledge. London: Routledge.

Freeman, D., \& Johnson, K. (1998). Reconceptualizing the knowledge base of language teacher education. TESOL Quarterly, 32, 397-418. http://dx.doi.org/10.2307/3588114

Freeman, D., \& Johnson, K. (2005). Response to Tarone and Allwright. In D. Tedick (Ed.), Second language teacher education: International perspectives (pp. 25-32). Mahwah, NJ: Lawrence Erlbaum.

Frow, J. (1989). Formal method in discourse analysis. Journal of Pragmatics, 13(3), 333-341. http://dx.doi.org/10.1016/0378-2166(89)90058-1

Gatbonton, E. (2000). Investigating experienced ESL teachers' pedagogical knowledge. Canadian Modern Language Review, 56(4), 585. http://dx.doi.org/10.3138/cmlr.56.4.585

Ghosh, R. (2011). The liberating potential of multiculturalism in Canada: Ideals and realities. Canadian Issues, 3-8.

Hyon, S. (1996). Genre in three traditions: Implications for ESL. TESOL Quarterly, 30(4), 693-722. http://dx.doi.org/10.2307/3587930

Kalan, A. (2013). Teaching ESL academic writing and intercultural rhetoric: A grounded theory study of practice in Ontario secondary schools. (Unpublished thesis). Ontario Institute for Studies in Education of the University of Toronto.

Kasper Loretta, F. (2000). The imagery of rhetoric: Film and academic writing in the discipline-based ESL course. Teaching English in the Two Year College, 28(1), 52-59.

Kaplan, R. (1966). Cultural thought patterns in intercultural education. Language Learning, 16(1), 1-20. http://dx.doi.org/10.1111/j.1467-1770.1966.tb00804.x

Kent, T. (1999). Post-process theory: Beyond the writing-process paradigm. Carbondale: Southern Illinois University Press.

Kubota, R., \& Lehner, A. (2004). Toward critical contrastive rhetoric. Journal of Second Language Writing, 13, 7-27. http://dx.doi.org/10.1016/j.jslw.2004.04.003

Larsen-Freeman, D. (1991). Consensus and divergence on the content, role, and process of teaching grammar. In J. Alatis (Ed.), Georgetown University roundtable on languages and linguistics 1991: Linguistics and language pedagogy (pp. 259-262). Georgetown, Washington, DC: Georgetown University Press.

MacPherson, S., Turner, D., Dustan Lafond, L., Hingley, W., Tigchelaar, A., \& Seonaigh Khan, R. (2004). ESL and Canadian multiculturalism: Multilingual, intercultural practices for the 21st century. TESL CANADA JOURNAL, 4, 1-22.

Martin, J. (2007, Oct 17). Canadians finally have bid a merciful farewell to official multiculturalism. The Province, 22. 
Meadmore, D., Hatcher, C., \& McWilliam, E. (2000). Getting tense about genealogy. Qualitative Studies in Education, 13(5), 463-476. http://dx.doi.org/10.1080/09518390050156413

Nespor, J., \& Barylske, J. (1991). Narrative discourse and teacher knowledge. American Educational Research Journal, 28, 805-823. http://dx.doi.org/10.3102/00028312028004805

Ontario College of Teachers. (2013, May 13). Retrieved from http://www.oct.ca/ /media/PDF/Standards\%20Poster/standards_flyer_e.ashx

Reeves, J. (2009). A sociocultural perspective on ESOL teachers' linguistic knowledge for teaching. Linguistics and Education, 20(2), 109-125. http://dx.doi.org/10.1016/j.linged.2008.11.001

Richards, J. C. (Ed.) (1998). Beyond training. New York: Cambridge University Press.

Scarboro, A., Campbell, N., \& Stave, S. (1994). Living witchcraft: A contemporary american coven. Westport, CT: Praeger.

Stabler, J. (2010). Canadian identity and Canada's Indian residential school apology. Unpublished manuscript.

Steinman, L. (2003). Cultural collisions in L2 academic writing. TESL Canada Journal, 20(2), 80-91.

Susser, B. (1994). Process approaches in ESL/EFL writing instruction. Journal of Second Language Writing, 3(1), 31-47. http://dx.doi.org/10.1016/1060-3743(94)90004-3

Tamboukou, M. (1999). Writing genealogies: An exploration of Foucault's strategies for doing research. Discourse: Studies in the Cultural Politics of Education, 20(2), 101-217. http://dx.doi.org/10.1080/0159630990200202

Tarone, E., \& Allwright, R. (2005). Second language teacher learning and student second language learning: Shaping the knowledge base. In Tedick, D. (Ed.), Second language teacher education. International perspectives (pp. 5-24). Mahwah, NJ: Lawrence Erlbaum.

Tatalovich, R. (1995). Nativism reborn? The official English language movement and the American states. Lexington, KY: University of Kentucky Press.

Van, Dijk, T. (n.d.). What do we mean by "discourse analysis"? Retrieved May 14, 2013, from http://www.discourses.org/journals/das/whatisdiscourseanalysis/index.html

Van, Houtum, H., \& Van, Naerssen, T. (2002). Bordering, ordering and othering. Tijdschrift Voor Economische En Sociale Geografie, 93(2), 125-136. http://dx.doi.org/10.1111/1467-9663.00189

Walker, D. (2011). How to teach contrastive (intercultural) rhetoric: Some ideas for pedagogical application. New Horizons in Education, 59(3), 71-81.

Wente, M. (2010, Oct 07). A few frank words about immigration. The Globe and Mail.

Wiley, T. G. (2007). Accessing language rights in education: A brief history of the US context. In O. Garcia, \& C. Baker (Eds.), Bilingual education: An introductory reader (pp. 89-105). New York: Multilingual Matters LTD.

Young, R. (Ed.) (1981). Untying the text: A post-structural anthology. Boston, MA: Routledge \& Kegan Paul.

\section{Note}

Note 1. "The term 'killing the Indian in the child' is widely used in referring to the goal of Canada's Indian Residential schools and it is difficult to attribute it to any particular source. It may have evolved from 'Kill the Indian, Save the Man' a phrase used by Richard Pratt, the architect of the U.S. Residential School System-for further information see Churchill, Ward, 2004. Kill the Indian, Save the Man: The Genocidal Impact of American Indian Residential Schools. San Francisco: City Lights." (Stabler, 2010, p.1)

\section{Copyrights}

Copyright for this article is retained by the author(s), with first publication rights granted to the journal.

This is an open-access article distributed under the terms and conditions of the Creative Commons Attribution license (http://creativecommons.org/licenses/by/3.0/). 